\title{
The Pension System in Slovenia in Light of Current International Macroeconomic Changes and Trends
}

Primož Dolenc*

\section{Abstract:}

The paper presents the results of a study that sheds light on the pension system and its dilemmas in Slovenia in light of current international macroeconomic changes and trends. We found that Slovenia has a pension system similar to that of other comparable economies (with the exception of the second pillar) and that it currently faces similar dilemmas as other economies that are resulting in inevitable reforms of the pension system. On the basis of international comparison and current demographic trends in Slovenia we proposed some policy recommendations for future reforms of the pension system in Slovenia.

Key words: pension systems, reforms, demographic changes

JEL: G23, J11

DOI: $10.2478 / v 10033-011-0002-2$

\section{Introduction}

Recent demographic trends and their effects on the pension systems are a challenging task for the economic policy of most developed and transitional countries around the world. Especially in economies with ageing populations, pension systems face sustainability issues and thus force economic policy, pension funds as well as individuals to reconsider the future of pensions and pension systems.

Modern pension systems are usually based on a MultiPillar structure with typically three pillars, (a) a "first-pillar" contributory system that is linked to varying degrees to earnings and seeks to replace some portion of income; (b) a mandatory "second pillar" that is essentially an individual savings account but can be constructed in a variety of ways; (c) voluntary "third-pillar" arrangements that can take many forms (individual, employersponsored, defined benefit, defined contribution). Pension systems as such usually combine two different parts, i.e., a redistributive part and an insurance part. The first guarantees a minimum life standard for pensioners, whereas the second part enables targeted pension receipts upon retirement (Holzmann and Hinz 2005).
In EU and OECD countries pension systems are very similar and only differ partly in their structure and relations between different pillars. These differences are mainly due to the different foundations of the systems and also the differences in the level of adjustments to recent demographic and socio-economic trends. In most of these countries reforms of pension systems were stimulated as a consequence of an ageing population, changes in the basic logic of the pension system, pressures on public finances, socio-economic changes, globalization and others. Reforms mostly relate to the socalled first pillar of "pay-as-you-go" (PAYG) pension systems, and which are due to the fact that traditional PAYG systems are usually not self-sufficient (or unconditionally sustainable) in new macroeconomic conditions. These changes, however, differ among countries, but the underlying fact is that similar recent

\footnotetext{
* Primož Dolenc

University of Primorska,

Faculty of Management Koper

email:primoz.dolenc@fm-kp.si
} 
demographic trends call for longer participation, lower benefits, changes to the pension system's parameters and other adjustments.

From this perspective Slovenia is not an exception, as it has an extremely old population and unfavorable expected trends. Therefore, it faces dilemmas to those of other comparable economies: the sustainability of its pension system, and what its appropriate structure and necessary adjustments should be. The purpose of the present paper is to shed light on trends and the necessary reforms of the pension system in Slovenia. Therefore, the Slovenian pension system and recent changes are confronted with pension systems in similar economies, and policy recommendations are given.

The paper is organized as follows. In the next section the methodology and data are presented. In section 3 we present some trends in economies that are similar to Slovenia from the perspective of demographic trends and pressures on pension systems. In section 4 we present the current pension system in Slovenia, some demographic trends and the dilemmas of facing its pension system. Before our conclusion we present policy recommendations.

\section{Methodology and Data}

The research employs comparative analysis of pension systems in EU and OECD countries. Here we resume and lean heavily on research made for the World Bank by Holzmann and Hinz (2005). This comparative analysis is the starting point for putting Slovenia in an international context. We use here the regulatory framework for the pension system in Slovenia, especially the Pension and Disability Insurance Act. We further employ inductive analysis and try to find common points in different pension systems of EU and OECD economies and apply these to the Slovenian case.

In estimation of the efficiency and sustainability of the Slovenian pension system we use statistical data from the Slovenian Statistical Office and the Slovenian Pension and Disability Fund. Demographic and financial data are taken into consideration, especially age structure, trends of average age and age structure, and financial transfers from the central budget to the pension fund. Based on this data we estimate future developments in age structure, which is (accompanied by a comparative analysis) a basis for policy recommendations. An explanation of methodology and data is presented in more detail in relevant sections.

\section{The recent dilemmas of modern PAYG pension} systems

Almost all European economies face similar problems: 1) the lowering number of active participants in the pension fund, and 2) the increasing number of retirees (see Whitehouse 2007 for more details). These trends were due to lower economic activity and a changed economic system.

These two facts consequently lead to several issues. The first is a fiscal problem. From a short-term perspective, pension systems are often blamed for unsustainable public finances, even though this might not be the real reason for questionable fiscal trends (see e.g. Dolenc and Stubelj 2010) - therefore reforms of the pension systems are underlined as necessary. From a long-term perspective, however, many pension systems, especially in transitional economies, are unsustainable due to population ageing (see Hagemann and Nicoletti 1989, and World Bank 1994).

Further, several socio-economic changes are obvious if we look at developments since the last decades of the $19^{\text {th }}$ century (approx. when the pension systems were introduced). At first pension systems had a significantly different proportion of retirees to the active population than today. Namely, Holzmann and Palmer (2006) note that initially the pension system was intended to help the widows and children of an insurant, because full retirement was achieved by a low proportion of the latter. Vodopivec and Dolenc (2008) point out that pension system benefits have been increasing in the last decades, while contributions have been - paradoxically decreasing. If all other effects are neglected, increasing life expectancy alone calls for reforms. Further, Kohli and Rein (1991) stress that in spite of higher life expectancy, people in modern economies work less and less.

Globalization also plays an important role. Economies have to use the advantages and reduce the negative effects of globalization when reforming their pension systems. Globalization brings higher labor force mobility among occupations, the public/private sector, regions and lastly the economies as such. The modern pension system should take these facts into consideration and adapt to them accordingly.

Turning to actual trends in economies similar to that of Slovenia, several changes can be noted. First, almost all developed and transition economies have changed by now the pension system according to which outflows are adjusted. Pensions are now mostly inflation indexed 
instead of nominal wage growth indexed. In addition, the formulae for the calculation of benefits and contributions have changed, sometimes dramatically.

Second, the retirement age has been steadily increasing due to a relatively low initial retirement age. In addition, the period for the calculation of pension benefits has been prolonged, causing lower pension benefits for retirees. There are some economies under which the benefits are not bound to years of participation and amounts (see Lindeman, Rutkowski and Sluchynskyy 2001 for details). The latter measure was introduced to address poverty issues.

According to Holzmann and Hinz (2005) almost all transition economies have introduced a full featured three-pillar pension system. This helped the formation of private and public funded schemes, which are mandatory and therefore accumulate more funds as voluntary schemes under the third pillar. The exceptions are the Czech Republic, Moldova, Turkey and Slovenia, which have not fully incorporated the second pillar.

\section{A summary of the pension system,}

\section{demographic trends and dilemmas of the pension system in Slovenia}

\subsection{General information on the pension system}

Slovenia has a similar pension system to that of other EU member states; however, there are some particularities. According to the definition of Holzmann and Hinz (2005) Slovenia has two pillars:

a) First Pillar: public pension system, mandatory and "Pay-As-You-Go", and

b) Third Pillar: private pension system, voluntary and funded pension scheme.

Two parts of the pension system are missing. First, Slovenia has no basic pillar - it does have a kind of minimum pension that is part of the first pillar, however. Yet of more concern is the fact that there is also a very limited second pillar as a mandatory, insurance-based and replacement rate increasing pension scheme. The later is mandatory only for some occupational groups.

The pension system has been somewhat reformed in the late $90 \mathrm{~s}$ and in 2005. At full retirement age the pension benefits depend only on participation period (and the level of contributions) - the full age was adjusted a decade ago. Currently the full retirement age for women is 61 years $^{1}$ and 63 for men. ${ }^{2}$ A comparison with other, similar economies (for a review see Whitehouse 2007) clearly shows that despite reform, the retirement age is still the lowest in the EU (besides Italy).

The minimum retirement age is now set as follows:

- 58 years on condition of a 40-year participation period,

- 63 years (men) and 61 years (women) on condition of a 20-year participation period and

- 65 years (men) and 63 years (women) on condition of a minimum 15 -year participation period.

If an individual exceeds a participation period ( 40 years for men and 38 years for women), additional participation brings premiums to pension benefits. These account for $3 \%$ (for the $41^{\text {st }}$ participation year) down to $1.5 \%$ (45 or more years). Further, some adjustments are introduced in case of an early/late retirement age. We address these issues later on.

\subsection{Demographic trends and the dilemmas of the pension system}

Slovenia faces unfavorable demographic and other changes that will affect its pension system's sustainability. In spite of reforms, the question of the pension system's sustainability remains. Several facts are obvious. In Slovenia, demographic trends are extremely unfavorable from the perspective of the pension system - the population is ageing. The age structure (Figure 1) shows that the Slovenian population is old (similar to EU25 data); the majority of the population is currently in its active age. The average age of the population is growing (Figure 2) - in the last 30 years the average age has increased 6 years. Furthermore, the structures of the young (15 years or younger) and old (65 years and more) populations are converging with negative effects (Figure 3).

A simple calculation, based on a linear trend and its extrapolation (ceteris paribus), shows that until the year 2020 the share of the young population could fall below $10 \%$ (to approx. 7\%), while the share of the old population - on the other hand - could increase to even

\footnotetext{
1 This retirement age will be achieved not before 2022, while the full retirement age for women has been increasing for 4 months yearly from the level of 54 years in 2002.

${ }^{2}$ It has been increasing for 6 months yearly from 59.5 in 2002.
} 


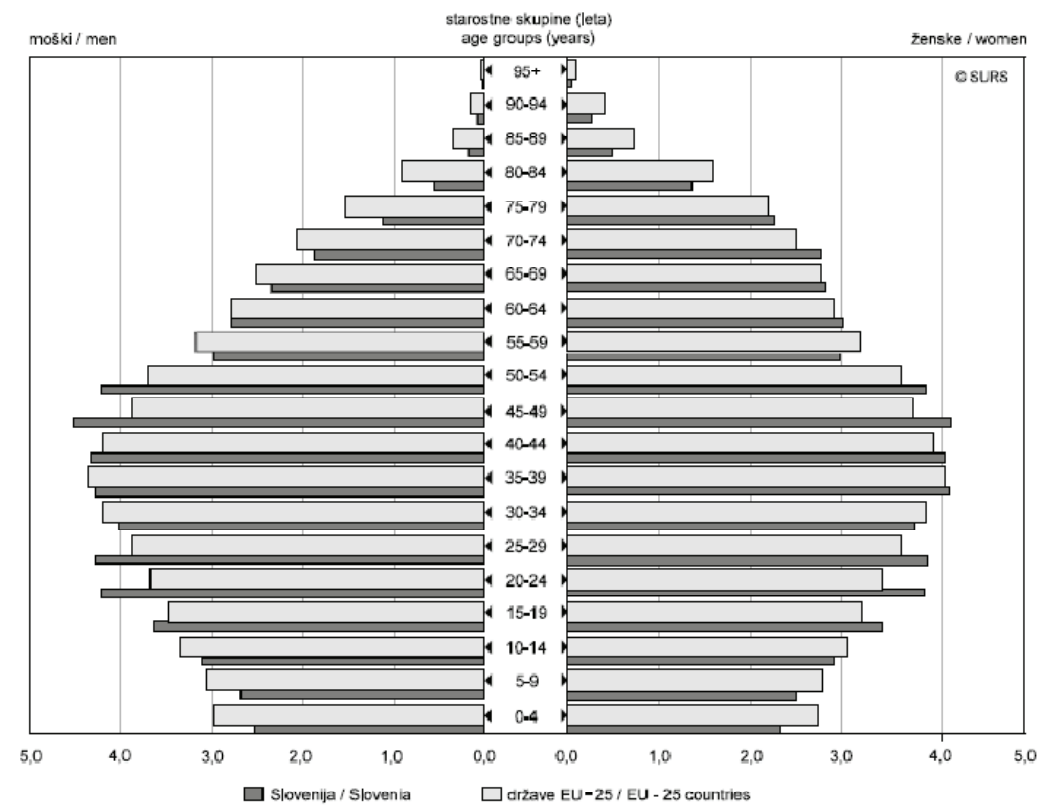

Source: Slovenian Statistical Office.

Figure 1: Population of Slovenia and EU15 (structure according to gender and age); data for year 2003

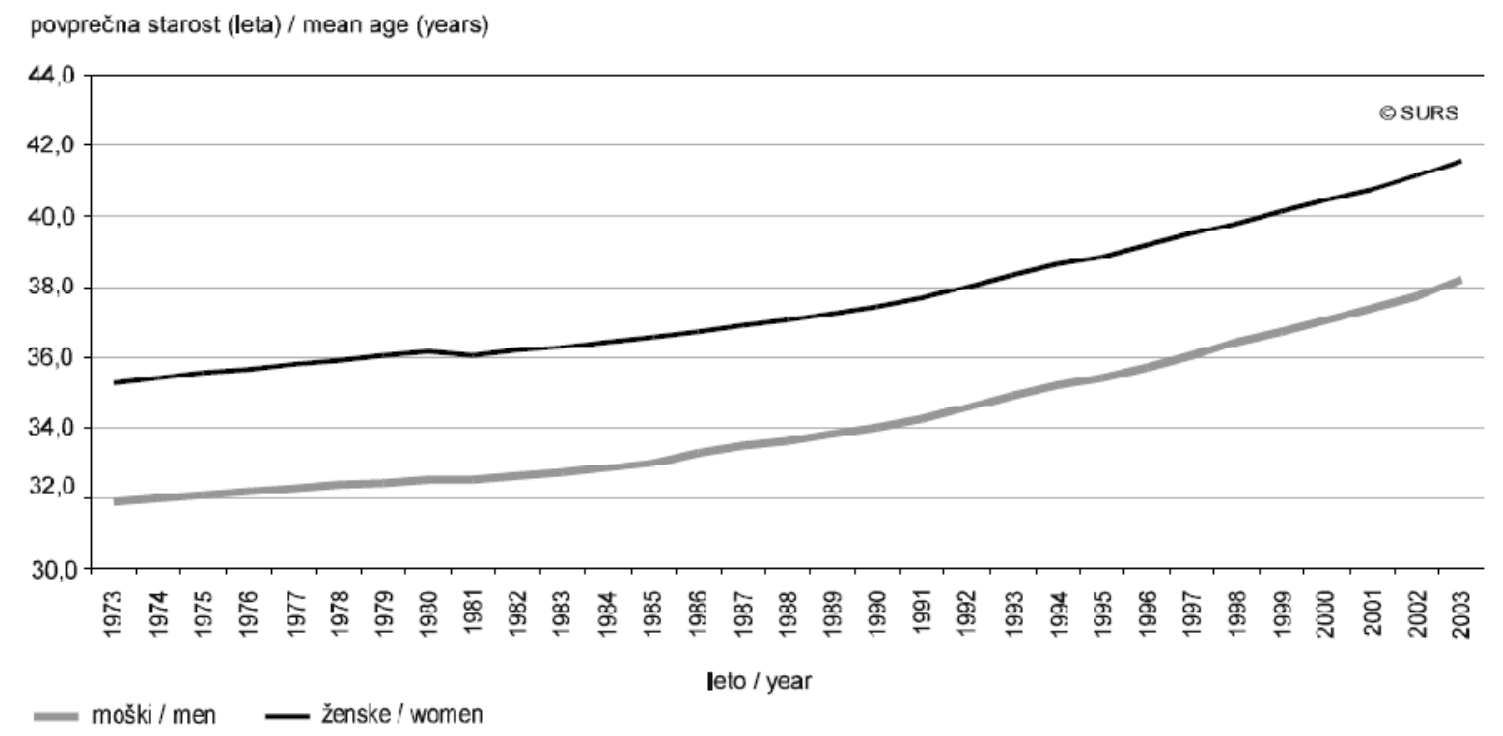

Source: Slovenian Statistical Office.

Figure 2: Average age in Slovenia

over 20\% (Figure 4). This trend reflects the lower old to active population ratio, causing problems for the pension system.

In spite of the fact that life expectancy has been increasing in Slovenia in the last decades, the individual payments to the pension system have not followed. Some adjustments were made after the last reform, but these changes have not been sufficient.

There is also the question of the sustainability of the Slovenian pension system per se, especially if we look at the financial report of the first pillar. While it is a general postulate that a sustainable PAYG pension system should be "self sufficient," in Slovenia the central budget is obligated (according to article 233 of the Pension and Disability Insurance Act) to cover the eventual negative balance of the first pillar. Such transfers from the central budget were permanent in the last decade or more and accounted for 15 to $20 \%$ of all of the pension fund's income. 


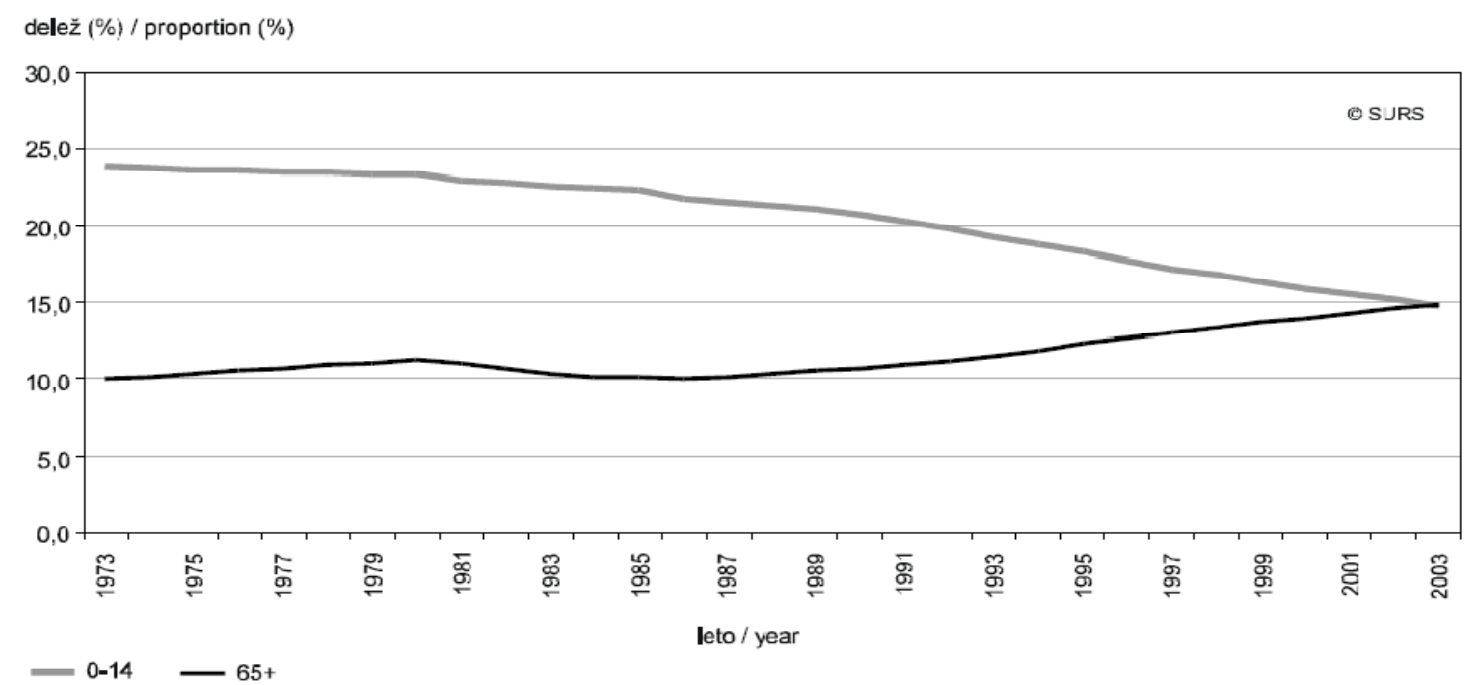

Source: Slovenian Statistical Office.

Figure 3: The share of the young population (15 years or less) and old population ( 65 years and more) in Slovenia

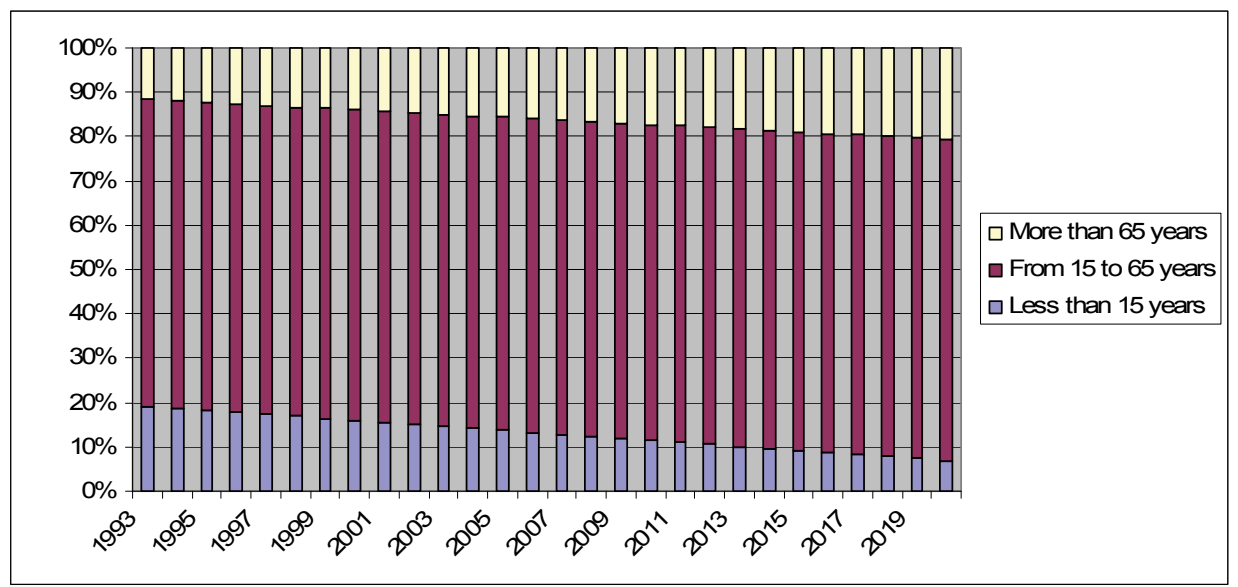

Source: Slovenian Statistical Office (data until year 2006) and own calculations (from year 2007 onwards).

Figure 4: Estimated structure of population in Slovenia until year 2020

This brief analysis and especially other analyses (see Verbič 2007a and 2007b, Verbič, Majcen and Nieuwkoop 2006) show that due to unfavorable general trends the pension system could become (if not the case even now) unsustainable unless some more dramatic changes/reforms take place. We discuss some possibilities in the next section.

\section{Policy recommendations}

According to the recent developments reviewed above, we propose several points for future pension system reforms in Slovenia:

- extension of the effective participation period,

- adjustments of some parameters of the pension system,
- introduction of the second pillar,

- eventual introduction of the basic pillar.

\subsection{Extension of the effective participation period}

International examples show that the participation period has to be extended in order to make a pension system sustainable. This holds especially for economies with demographic trends similar to those noted in Slovenia. There are, however, some dilemmas in extending working lives. Several authors (see Kohli and Rein 1991, Palacios 2003, Burtless and Quinn 2002, Vodopivec and Dolenc 2008 and others) argue that as people view retirement as their "entitlement," extending working lives is not an easy task. And the problem is not 
confined to workers - employers, too, are reluctant to employ old workers.

There are, however, some possible measures on the workers' side; Vodopivec and Dolenc (2008) summarize some of them. The crucial measure could be a financial reward for extending working life (extending the participation period). If workers are financially rewarded for working longer, they might be more reluctant to retire as soon as they achieve retirement conditions. There are some inconsistencies in practice. In Slovenia, the pension system stimulates the extension of working life, but after 66 years of age the extension of working life does not increase pension benefits - the probability that one will work longer and postpone his/her right to claim pension is thus low. The pension system should reflect the real financial effect of early/late retirement. We discuss the necessary changes to parameters later on.

Alternative, flexible work arrangements can encourage the elderly to work longer. Ruhm (1990) and Friedberg (2007) found that old workers prefer more flexible work arrangements (that is, part-time or shorter-hour jobs) as such "bridge" jobs suit old workers on their path to retirement. This increase was particularly notable among relatively educated and well-off workers. Thus, the pension system in Slovenia should encourage workers/retirees to take alternative work arrangements after full entitlement, while receiving some benefits from the pension system.

Making old people healthier will also contribute to their desire to work longer. Not surprisingly, research shows that poor health has a negative effect on the likelihood of being in the workforce, on expected retirement age, as well as hours worked and wages (for a survey, see Currie and Madrian 1999).

How can employers be encouraged to offer more jobs to older workers? Introducing flexible wage determination can increase the employability of old workers, if institutional rigidities prevent wages adjusted to changes in the life-cycle productivity of workers (Vodopivec and Dolenc 2008). In Slovenia, however, the law and collective agreements still mandate a 0.5 percent increase of wage level per year of work experience, making older workers less competitive.

On the other hand, improving the employability of older workers should be encouraged. To increase the attractiveness of older workers to employers, new generations of older workers should possess better skills, which call for life-long learning - including learning toward the end of their work careers. Indeed, several considerations speak in favor of such development. First, if the anticipated age of retirement increases, the "break even" age of training increases, as the payoffs to training are spread over a longer work period. Second, the OECD (2003) also argues that if workers undergo continued training throughout their careers, it is unlikely that they will experience a decline in their trainability in old age. Third, because the retention rates of older workers are high, training older workers may be as profitable as training younger ones.

\subsection{Adjustments of some parameters of the pension system}

The problem of the modern "Pay-As-You-Go" first pillar of pension systems is that it cannot adjust to relevant demographic and other changes in the economy or the necessary adjustments are too slow. In Slovenia, pensions are average wage adjusted, taking into consideration no other relevant factors. Holzmann and Palmer (2006), Börsch-Supan (2006), Barr (2006) have introduced an idea of a notional-defined contribution pension scheme (NDC), where the sustainability of the "Pay-As-You-Go" first pillar is achieved by the more flexible parameters of the latter. In such a system the pension benefits are adjusted according to selected parameters, which affect the pension system: the size of the active population, wage growth, fiscal policy... a similar system could be adopted in Slovenia as well, while not changing much the existing first pillar and in fact ensuring its sustainability.

Further, the existing financial bonuses/penalties for late/early retirement have to be revised. We estimated for this purpose the effect of late/early retirement on the level of individual pensions for both men and women with average wages and its effect on the pension system. On the level of the pension system we calculated the present value of expected additional or lower payments. On the individual level we calculated:

a) additional or lower pensions according to current regulation and

b) expected/fair additional or lower pensions based on the estimated present value of the expected additional or lower payments (taken from the calculation for the pension system), divided on a monthly basis using expected life-expectancy for men/women and a financial annuity approach. The calculations have been made in a no-inflation environment. 


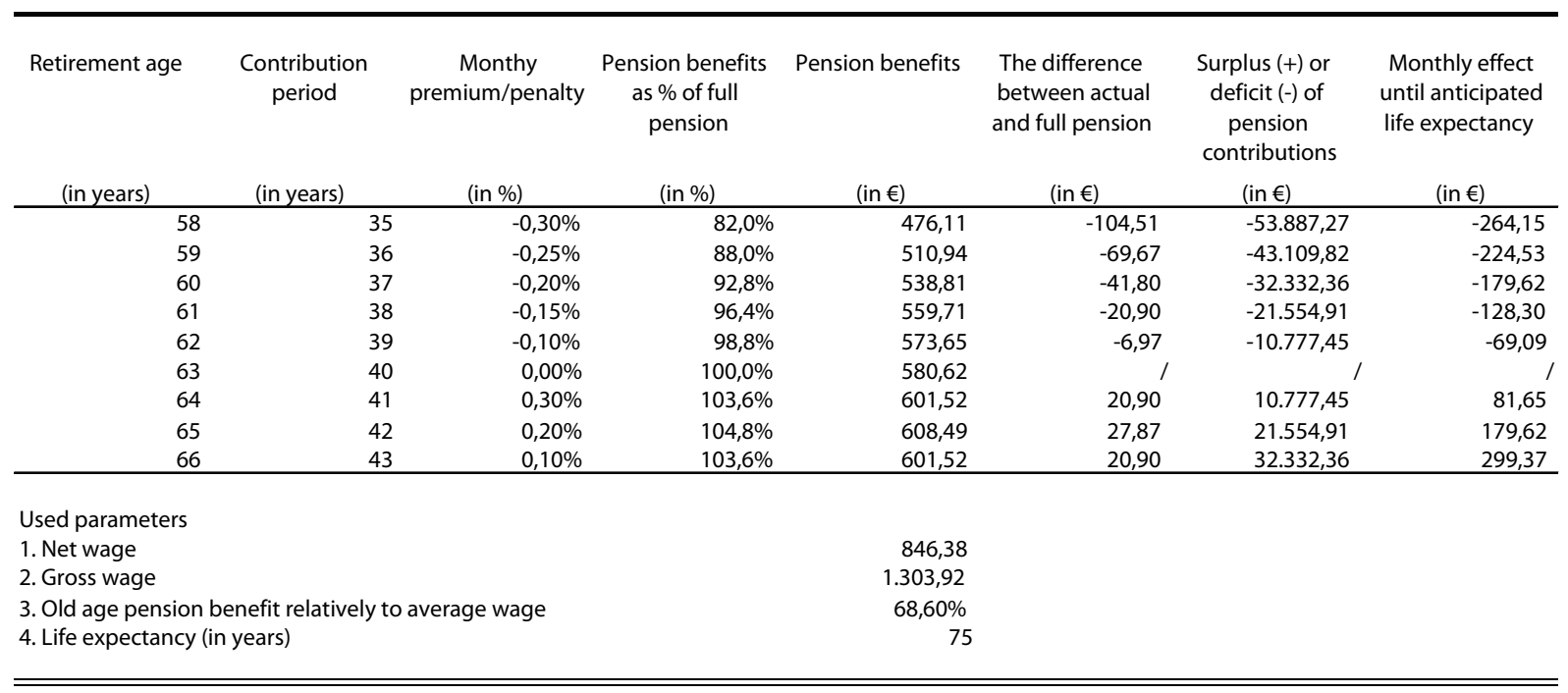

Source: Slovenian Pension and Disability Insurance Act, Slovenian Statistical Office and own calculations.

Table 1: The calculation of premium/penalty for late/early retirement for men

\begin{tabular}{|c|c|c|c|c|c|c|c|}
\hline Retirement age & $\begin{array}{l}\text { Contribution } \\
\text { period }\end{array}$ & $\begin{array}{c}\text { Monthy } \\
\text { premium/penalty }\end{array}$ & $\begin{array}{l}\text { Pension benefits } \\
\text { as \% of full } \\
\text { pension } \\
\text { (in \%) }\end{array}$ & Pension benefits & $\begin{array}{l}\text { The difference } \\
\text { between actual } \\
\text { and full pension } \\
\text { (in €) }\end{array}$ & $\begin{array}{l}\text { Surplus }(+) \text { or } \\
\text { deficit }(-) \text { of } \\
\text { pension } \\
\text { contributions } \\
\text { (in } €)\end{array}$ & $\begin{array}{l}\text { Monthly effect } \\
\text { until anticipated } \\
\text { life expectancy } \\
\text { (in } €)\end{array}$ \\
\hline 58 & 35 & $-0,30 \%$ & $89,2 \%$ & 517,91 & $-62,71$ & $-32.332,36$ & $-112,27$ \\
\hline 59 & 36 & $-0,25 \%$ & $94,0 \%$ & 545,78 & $-34,84$ & $-21.554,91$ & $-78,10$ \\
\hline 60 & 37 & $-0,20 \%$ & $97,6 \%$ & 566,68 & $-13,93$ & $-10.777,45$ & $-40,82$ \\
\hline 61 & 38 & $0,00 \%$ & $100,0 \%$ & 580,62 & & & \\
\hline 62 & 39 & $0,30 \%$ & $103,6 \%$ & 601,52 & 20,90 & $10.777,45$ & 44,91 \\
\hline 63 & 40 & $0,20 \%$ & $104,8 \%$ & 608,49 & 27,87 & $21.554,91$ & 94,54 \\
\hline 64 & 41 & $0,10 \%$ & $103,6 \%$ & 601,52 & 20,90 & $32.332,36$ & 149,69 \\
\hline \multicolumn{8}{|l|}{ Used parameters } \\
\hline \multicolumn{4}{|l|}{ 1. Net wage } & 846,38 & & & \\
\hline \multicolumn{4}{|c|}{ 2. Gross wage } & $1.303,92$ & & & \\
\hline \multicolumn{4}{|c|}{ 3. Old age pension benefit relatively to average wage } & $68,60 \%$ & & & \\
\hline \multicolumn{4}{|c|}{ 4. Life expectancy (in years) } & 82 & & & \\
\hline
\end{tabular}

Source: Slovenian Pension and Disability Insurance Act, Slovenian Statistical Office and own calculations.

Table 2: The calculation of premium/penalty for late/early retirement for women

Tables 1 and 2 show that men with an average wage receive only $€ 20$ monthly more if they prolong their working activity for a year after meeting the full retirement criteria. The full (present value) effect for the pension system is almost $€ 11,000$, which means that the financial reward should in fact be at least $€ 80$ monthly (at a life expectancy of 75 years). On the other hand, the penalties for early retirement are too low: if a men retires 5 years before meeting full retirement conditions, his monthly loss in pension would be approx. $€ 100$, whereas the effective loss for the pension system would be more than $€ 260$ monthly. Similar results were found for women. Our simulations show that penalties for early retirement had to be increased (to $0.75-1.00 \%$ per month for men and $0.55-0.60 \%$ per month for women), as well as incentives for late retirement (to 1.1-1.4\% per month for men and $0.6-0.7 \%$ per month for women). These adjustments would equalize additional/lower contributions to the pension system with higher/lower pension benefits (in present value terms).

\subsection{Introduction of the second pillar}

Verbič (2007a) found that workers should invest $5 \%$ of their net wage in a funded pension scheme in order to keep their expected pension benefits the same as before the reforms in 1999 and 2005. However, contributions to the third pillar in Slovenia account for less than $0.4 \%$ of net wages. It is obvious that the voluntary pension 
scheme does not play its expected role - an insurance against income loss after retirement. Therefore, a mandatory second pillar (funded scheme) would probably be a proper solution for Slovenia as well. It could help the rising replacement rate and would also generate additional national savings.

\subsection{Introduction of the basic pillar}

As mentioned before, the basic pillar helps confronting basic poverty issues. These benefits are not directly linked to contributions to the pension system; therefore, benefits are usually not financed from the pension system, but more or less from the central budget. We suggest that following prior recommendations (hopefully resulting in the long-term self-sufficiency of the first pillar) funds that are currently transferred to the pension system due to the negative current result of the first pillar should be directed to the basic pillar.

\section{Conclusion}

This paper presents the results of a study that shed light on the pension system and its dilemmas in Slovenia in light of current international macroeconomic changes and trends. We found that Slovenia has a pension system similar to that of other comparable economies (with the exception of the second pillar) and that it currently faces dilemmas similar to those of other economies, resulting in inevitable reforms of the pension system. Slovenia also has an ageing population, causing substantial pressures on the pension system, and is faced with other current changes: socio-economic changes, pressures on fiscal policy, the challenges of globalization, etc. On the basis of international comparison and current demographic trends in Slovenia, we formed some policy recommendations for future reforms of the pension system in Slovenia.

We believe that four points have to be taken into consideration for future reforms. The first is the extension of the effective participation period due to higher life expectancy. This might be a challenging task, especially while workers and employers are not enthusiastic about extending working lives. Further, adjustments of some of the parameters of the pension system would be inevitable. Changes might go in the direction of a Notional Defined Contribution within the first pillar. In addition, penalties/premiums for early/late retirement have to be corrected so that they reflect the actual financial effects of participation. We suggest introducing the second pillar, because various empirical studies for Slovenia show that payments into the voluntary pension scheme are not sufficient to assure a sufficient living standard after retirement (contributions to the third pillar are less than a tenth of that desired). And lastly, the introduction of the basic pillar might be desirable - here the funds that are currently transferred to the first pillar due to its non-self-sufficiency might be used towards a poverty reduction scheme. ㄷ.

\section{References}

Barr, N. 2006. Non-Financial Defined Centribution Pensions: Mapping the Terrain. In Pension Reform, edited by R. Holzmann and E. Palmer, Washington D.C.: The World Bank.

Börsch-Supan, A.H. 2006. What Are NDC Systems? What Do They Bring to Reform Strategies? In Pension Reform, edited by R. Holzmann and E. Palmer, Washington D.C.: The World Bank.

Burtless, G., and J.F. Quinn. 2002. Is Working Longer the Answer for an Aging Workforce? Issues brief 11 (december). Boston: Center for Retirement Research at Boston College.

Currie, J., and B.C. Madrian. 1999. Health, Health Insurance, and the Labor Market. In Handbook of Labor Economics, edited by O.C. Ashenfelter and D. Card, Amsterdam: Elsevier Science Publishers BV.

Dolenc, P., and I. Stubelj. 2010. Fiscal sustainability in EU and current financial/economic crisis. International journal of sustainable economy 2(1): 80-91

Friedberg, L. 2007. The Recent Trend Towards Later Retirement. Issues in Brief 9 (marec). Boston: Center for Retirement Research at Boston College.

Hagemann, R.P., and G. Nicoletti. 1989. Population Ageing: Economic Effects and Some Policy Implications for Financing Public Pensions. OECD Economic Studies No. 12. Paris: OECD.

Holzmann, R., and R. Hinz. 2005. Old Age Income Support in the 21st Century. Washington D.C.: The World Bank.

Holzmann, R., and E. Palmer. 2006. Pension Reform. Washington D.C.: The World Bank.

Kohli, M., and M. Rein. 1991. The Changing Balance of Work and Reitrement. In Time for Retirement. Comparative Studies of Early Exit from the Workforce, edited by M. Kohli, M. Rein, A.M. Guillemard, and H. van Gunsteren, Cambridge: Cambridge University Press.

Lindeman, D., M. Rutkowski, and O. Sluchynsky. 2001. The Evolution of Pension Systems in Eastern Europe and Central Asia: Opportunities, Constraints, Dilemmas, and Emerging Practices. In OECD (Organisation for Economic Co-operation and Development): OECD Financial Market Trends 80. Paris: OECD.

OECD (Organisation for Economic Co-operation and Development). 2003. Taxing Wages. Paris: OECD.

Palacios, R. 2003. The Future of Global Ageing. International Journal of Epidemiology 31(4): 786-791.

Pension and Disability Act. Slovenian version available on-line: http://www.uradni-list.si/1/objava.jsp?urlid=2006109\&stevilka $=4646$ [15.8.2008].

Ruhm, C. 1990. Bridge Jobs and Partial Retirement. Journal of Labor Economics 8(4): 482-501. 
Slovenian Statistical Office, 2010. SI-Stat Data Portal available on-line: http://www.stat.si/pxweb/dialog/statfile1.asp [15.8.2008].

Verbič, M. 2007a. Varying the parameters of the Slovenian pension system: an analysis with an overlapping-generations general equilibrium model. Ljubljana: Institut za ekonomske raziskave.

Verbič, M. 2007b. Supplementary pension insurance in Slovenia: an analysis with an overlapping-generations general equilibrium model. Ljubljana: Institut za ekonomske raziskave.

Verbič, M., B. Majcen in R. van Nieuwkoop. 2005. Sustainability of the Slovenian pension system: An Analysis with an Overlapping-generations General Equilibrium Model. Working paper 29. Ljubljana: Institut za ekonomske raziskave.

Vodopivec, M., and Dolenc, P. 2008. Live Longer, Work Longer: Making it Happen in the Labor Market. SP Discussion Paper No. 0803. Washington D.C.: The World Bank.

WB (World Bank). 1994. Averting the Old-Age Crisis: Policies to Protect the Old and Promote Growth. New York: Oxford University Press.

Whitehouse, E. 2007. Pensions Panorama. Washington D.C.: The World Bank. 